\title{
Light Hydrocarbon Geochemistry of Oils in the Alpine Foreland Basin: Impact of Geothermal Fluids on the Petroleum System
}

\author{
E. Pytlak, ${ }^{1}$ A. Leis, ${ }^{2}$ W. Prochaska, ${ }^{1}$ R. F. Sachsenhofer, ${ }^{1}$ D. Gross, ${ }^{1}$ and H.-G. Linzer ${ }^{3}$ \\ ${ }^{1}$ Applied Geosciences \& Geophysics, University of Leoben, Peter-Tunner-Str. 5, 8700 Leoben, Austria \\ ${ }^{2} J R-A q u a C o n S o l ~ G m b H$, Steyrergasse 21, 8010 Graz, Austria \\ ${ }^{3}$ Rohöl-Aufsuchungs AG, Schwarzenbergplatz 16, 1015 Vienna, Austria
}

Correspondence should be addressed to Ł. Pytlak; lukasz.pytlak@onet.pl

Received 14 March 2017; Revised 17 June 2017; Accepted 20 July 2017; Published 17 September 2017

Academic Editor: Marco Petitta

Copyright (C) 2017 Ł. Pytlak et al. This is an open access article distributed under the Creative Commons Attribution License, which permits unrestricted use, distribution, and reproduction in any medium, provided the original work is properly cited.

\begin{abstract}
Oil is produced in the Austrian sector of the Alpine Foreland Basin from Eocene and Cenomanian reservoirs. Apart from petroleum, the basin hosts a significant geothermal potential, which is based on the regional flow of meteoric water through Malmian (Upper Jurassic) carbonate rocks. Oils are predominantly composed of $n$-alkanes, while some samples are progressively depleted in light aromatic components. The depletion in aromatic components relative to abundant $n$-alkanes is an effect of water washing. Waters coproduced with oils that are affected by water washing show a progressive reduction in salinity and depletion in ${ }^{2} \mathrm{H}$ and ${ }^{18} \mathrm{O}$ isotopes, indicating that the degree of water washing is mainly controlled by the inflow of meteoric water from the Malmian aquifer. In some fields with Cenomanian reservoir rocks, a hydraulic connectivity with the Malmian aquifer is evident. However, water washing is also recognized in Eocene reservoirs and in areas where the Malmian aquifer is missing. This shows that existing flow models for the regional Malmian aquifer have to be modified. Therefore, the results emphasize the importance of combining data from the petroleum and geothermal industry, which are often handled separately.
\end{abstract}

\section{Introduction}

The Alpine Foreland Basin (AFB) is a minor oil and moderate gas province in central Europe (Figure 1). The cumulative production of oil + condensate was about 9 mio. tons and 1.647 mio. Nm3 of associated gas (RAG production until 2015, industrial data). Main oil reservoirs are found in Cenomanian and Eocene horizons, whereas gas is mainly trapped in Oligomiocene rocks (Figure 2). Many studies have been performed to understand the petroleum systems in the basin. Within this context, organic geochemical, biomarker, and stable isotope data have been used to characterize organic matter type and source rock maturity, as well as oil migration and alteration processes (e.g., Schulz et al. (2002) [1-3]). However, all previous geochemical studies were based on the $\mathrm{C}_{15+}$ hydrocarbon fraction. In contrast, light hydrocarbons $\left(\mathrm{C}_{15-}\right.$ fraction) remained uninvestigated, although they are important proxies for facies and maturity of source rocks and migration and alteration processes (e.g., [4]).
The AFB not only is an important hydrocarbon province but also hosts a major geothermal potential (e.g., [5]), which is related to an active aquifer in Upper Jurassic carbonates ("Malmian aquifer" sensu [6]). The general characteristics of the Malmian aquifer such as charge and discharge area and residence time are reasonably well understood (e.g., [7]; Figure 3). In hydrogeological models, the Malmian aquifer is typically considered as separated from aquifers in overlying stratigraphic units [8]. However, Andrews et al. [7], Goldbrunner [9], and Gross et al. [10] suggested hydraulic connections between the Malmian aquifer and oil-bearing rocks. The interaction of water with hydrocarbons may result in the removal of relative water-soluble compounds (e.g., light aromatics: benzene, toluene, ethylbenzenes, and xylenes (BTEX)) from oil. In the petroleum industry, this process is generally called "water washing" (e.g., [11]). Simple numerical models of Lafargue and Thiez [12] showed that the removal of BTEX is limited by water velocity, if the water flow beneath the oil-water-contact is below $10 \mathrm{~cm} / \mathrm{year}$, and by rate of diffusion, if the water flow is higher. Meteoric water can also 


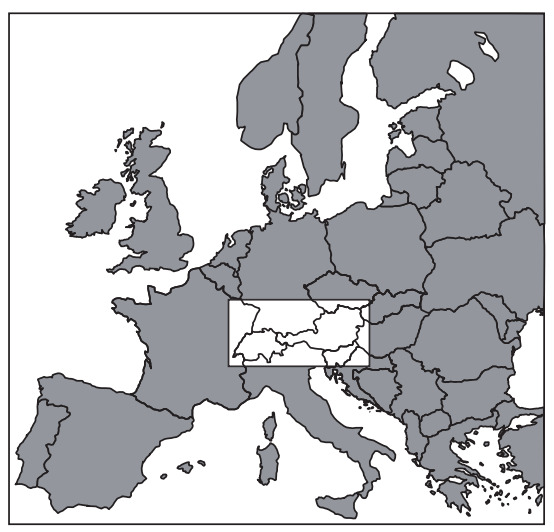

(a)

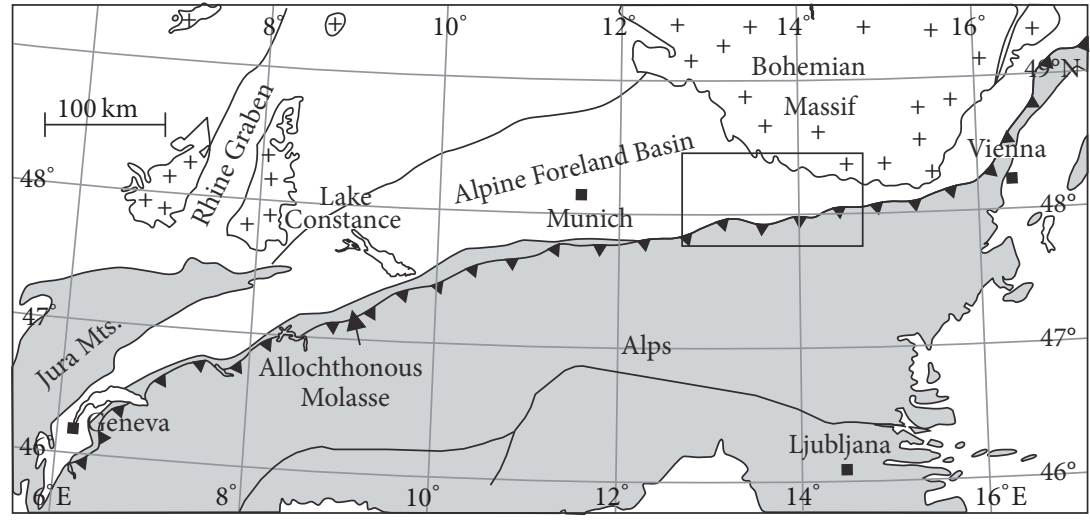

(b)

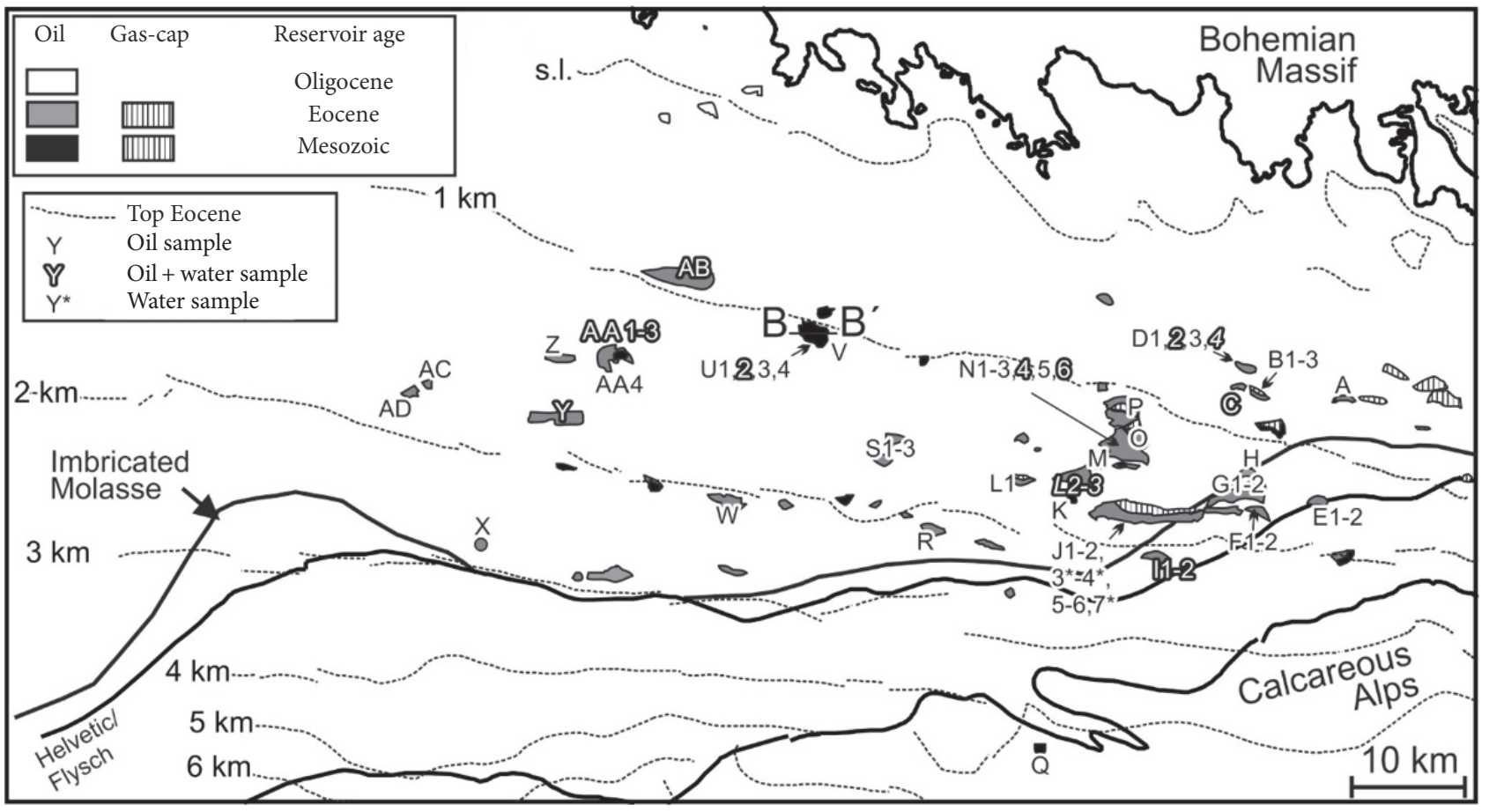

(c)

Figure 1: ((a) and (b)) Map of Europe with location of the study area in the Alpine Foreland Basin. (c) Distribution of oil fields together with the location of investigated samples. The B-B' cross section is presented in Figure 8.

introduce microbial communities into an oil reservoir and provide oxygen or electron acceptors and inorganic nutrients necessary for microbial activity (e.g., [13, 14]). Therefore, under suitable geological conditions, both processes are concomitant.

Hence, the main aim of this study is to reveal any effect of waters from the Malmian aquifer on the composition of oil in Cretaceous and Eocene reservoirs. In addition, information on the regional and stratigraphic distribution of water washing can help to refine and constrain the hydrogeological model.

To increase the regional coverage of the sample set, selected chemistry/isotope data of water from industry and Andrews et al. [7] are included in the present study. The comparison of these old data (often determined at the beginning of oil production) and data obtained after years of oil production may also reveal any influence of hydrocarbon production on water composition.

\section{Geological Background}

The asymmetric Alpine Foreland Basin (AFB) stretches along the northern margin of the Alps and dips below the Alpine nappes (Figure 1(b)). In the Upper Austrian sector of the Alpine Foreland Basin, the sedimentary succession overlies crystalline basement of the Bohemian Massif and comprises the following from bottom to top: Permo-Carboniferous graben sediments, Jurassic and Upper Cretaceous mixed carbonate-siliciclastic shelf sediments, and Eocene to Upper Miocene Molasse sediments (Figure 2). 


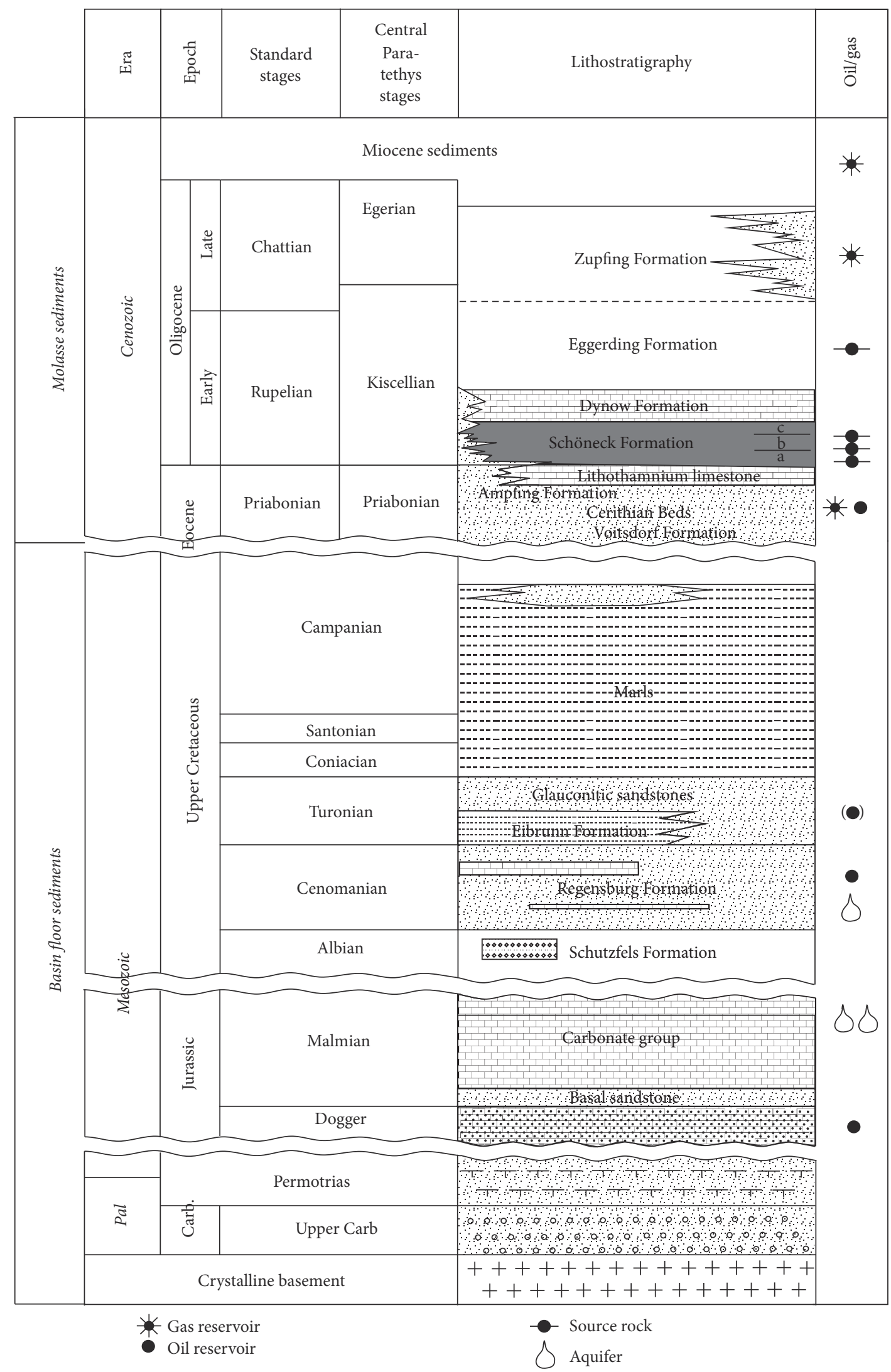

Figure 2: Time stratigraphic table of the Austrian part of the Alpine Foreland Basin; source rock and oil and gas occurrences are indicated (after [15-17]). 


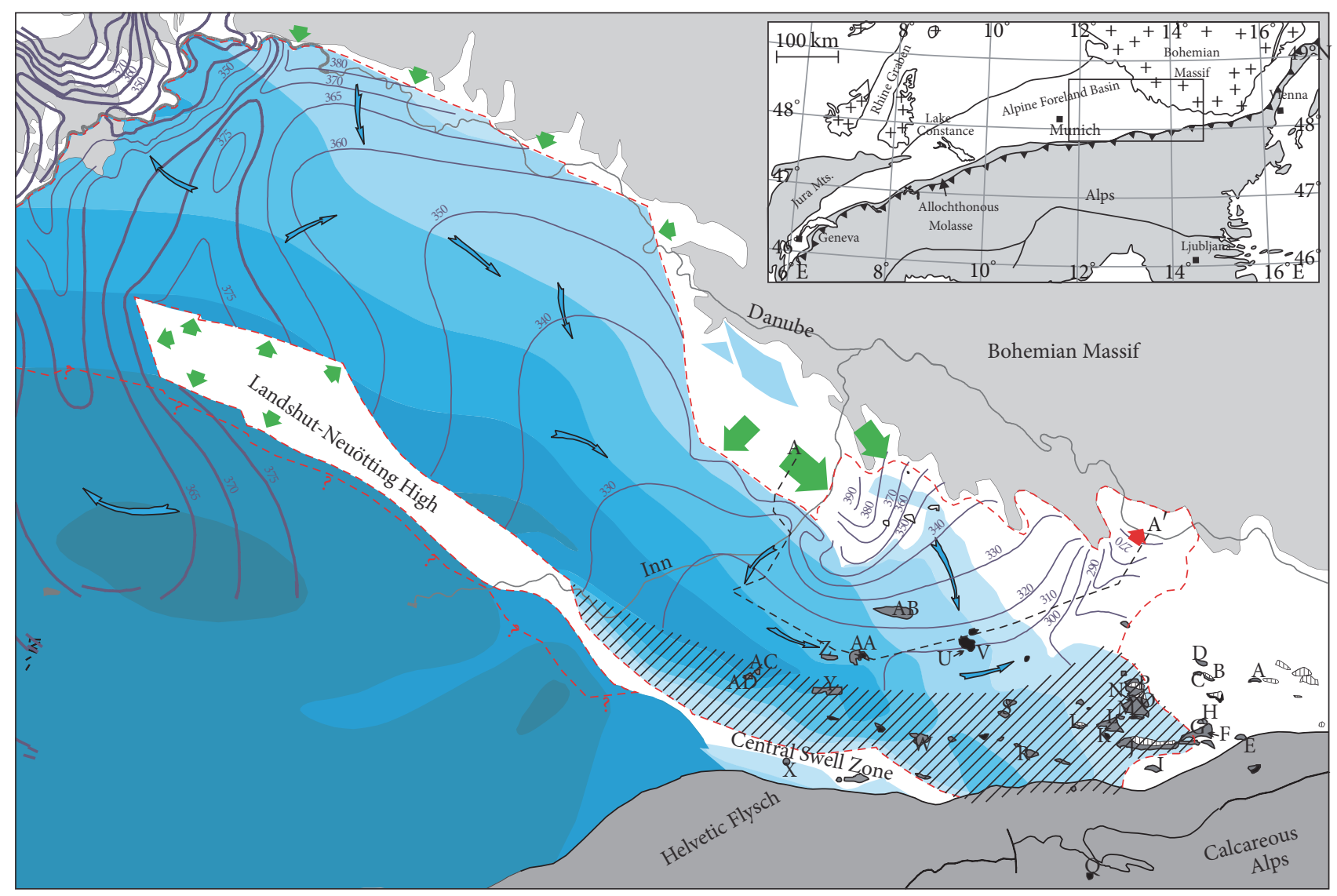

\footnotetext{
- Area of water charge

$\checkmark \quad$ Direction of flow of thermal water

- Area of water discharge

330 Lines of equal potential of the thermal water aquifer

-.- Contour line of thermal water aquifer

IIII/ Area of high salinity thermal water
}

Hydrocarbon system

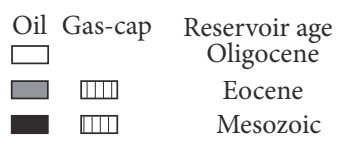

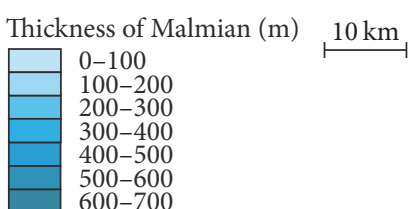

Figure 3: Thickness map of the Malmian horizon. Simplified thermal water system, regional water flow (modified from [8]), and location of oil fields are indicated. Inset presents location of map. Faults have been omitted to clarify the look of the map. The A- $\mathrm{A}^{\prime}$ cross section is presented in Figure 4.

Autochthonous Jurassic and Cretaceous sediments form the basin floor. The Upper Jurassic carbonate group (Figure 2), comprising limestones and dolostones, is up to $500 \mathrm{~m}$ thick (Figure 3). These fractured and karstified carbonates are the most important deep aquifer for thermal water (Malmian aquifer) but are absent in the northern and eastern part of the study area due to erosion [5]. Because Malmian connate brines have been replaced by meteoric water (average total mineralization is $2.2 \mathrm{~g} / \mathrm{l}$ [9]), the Malmian water differs hydrochemically and isotopically from waters in overlying horizons. High salinity water in Malmian rocks is found only in the southern part of the basin, indicating stagnant conditions in this area ([7], Figure 3). Recharge and discharge of the Malmian aquifer take place mainly at the basin edges, often through permeable Cenozoic sediments or fractured basement rocks $[8,27]$.

Main oil and associated gas reservoir rocks are Cenomanian and Eocene shallow marine sandstones (Figure 2).
Minor hydrocarbon deposits are also found in Jurassic clastic rocks and Upper Eocene algal limestones (Lithothamnium limestone). The main source rocks for thermogenic hydrocarbons are deep marine Lower Oligocene pelitic rocks (Schöneck Fm. and Eggerding Fm. [1, 28]), which became mature beneath the Alpine nappes in Miocene time [29]. The lateral migration distance of oil in the Austrian part of the Alpine Foreland Basin varies from less than 20 to more than $50 \mathrm{~km}[2,3]$. Hydrocarbon migration commenced simultaneously with hydrocarbon generation and continued until the present day [29]. The hydrocarbon habitat is strongly influenced by Neogene uplift and erosion [30]. Neogene tilting of the basin changed migration pathways and oil-watercontacts ([30, 31]; Linzer, pers. comm.). Heavily biodegraded oils occur along the northern margin of the basin in shallow marine Oligocene sands (Figure 1).

Gratzer et al. [2] recognized two oil families. The western oil family (west of $S$ field) contains more sulfur than 


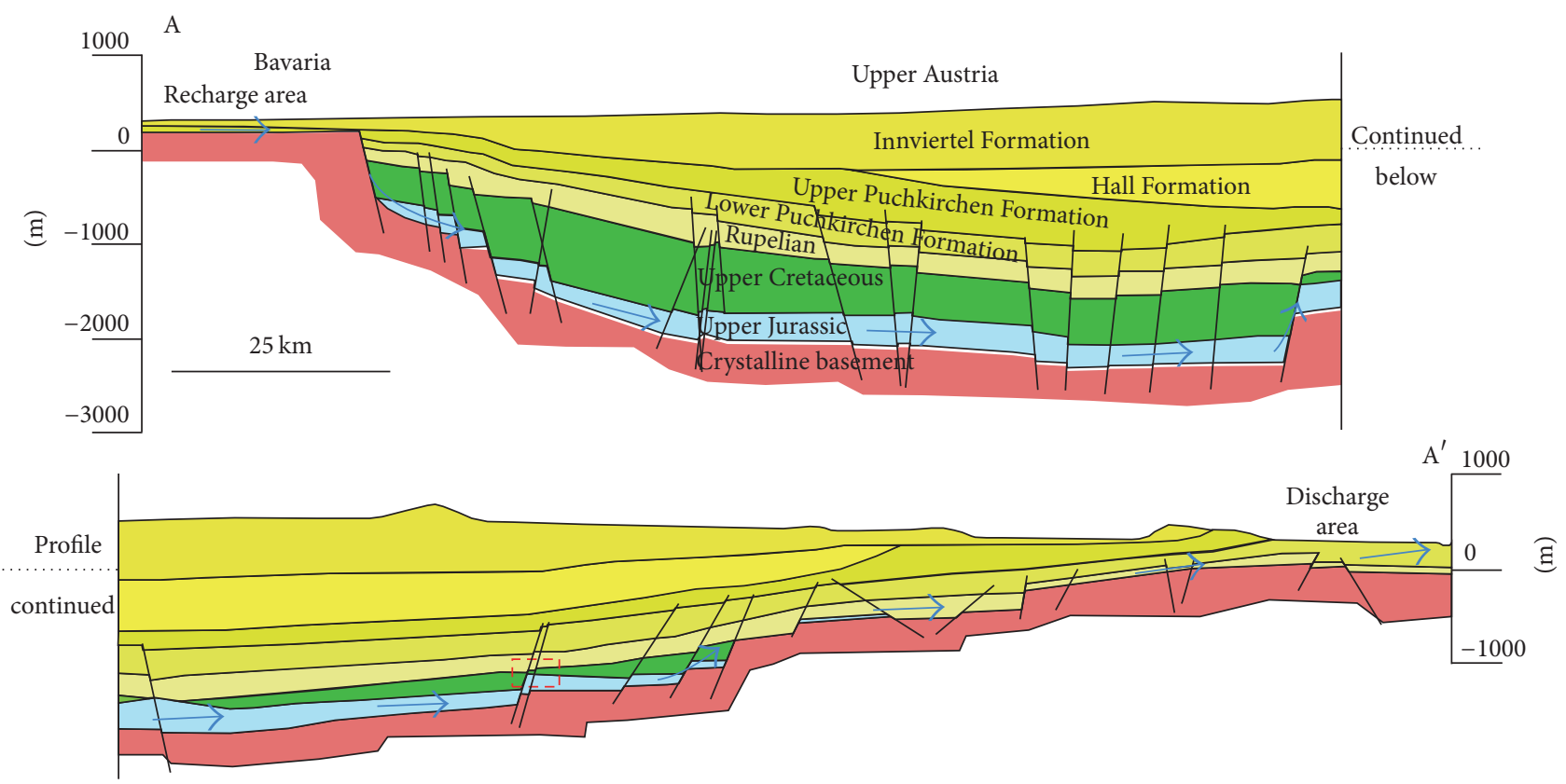

FIGURE 4: Regional cross section from the recharge area in Lower Bavaria to the discharge area west of Linz (Upper Austria) (modified from [6]). Position of cross section is indicated in Figure 3 by a dashed line. Area marked by red rectangle is displayed in Figure 8.

the eastern family (east of S field). Dibenzothiophene/phenanthrene $(\mathrm{DBT} / \mathrm{Ph})$ ratios are higher in the western oil family, indicating enhanced availability of reduced sulfur for incorporation into organic matter [32]. These variations reflect differences in the source rock facies beneath the Alpine nappes (see [28]).

Dry gas, traditionally interpreted as microbial in origin (e.g., $[33,34]$ ), prevails in clastic deep water sediments with an Oligocene (Lower Puchkirchen Fm.) or Miocene age (Upper Puchkirchen Fm., Hall Fm. [35-37]).

\section{Samples and Methods}

38 oil and 15 water samples were collected from producing wells operated by Rohöl-Aufsuchungs AG (RAG, Vienna, Austria) in 2013-2015. The sample code represents the field name by a capital letter. If several wells from a single field have been sampled, these are labelled by numbers; for example, samples D1 to D4 are taken from different wells in the D field (see Figure 1(c)). Special precautions were taken during sampling and laboratory handling to avoid any possible losses of volatile hydrocarbons. Glass bottles were filled with reservoir fluids (oil and water), immediately crimped, and stored at $4^{\circ} \mathrm{C}$. In the lab, water and oil were separated and stored in crimped bottles at $4^{\circ} \mathrm{C}$ for further investigations. In addition, oil and water samples from archives were also investigated.

Fresh and archival water samples (19 in total) were measured by ion chromatography. The samples were filtered through a $0.2 \mu \mathrm{m}$ nylon filter prior to analysis. The filtrate was diluted and analyzed for cations and anions using two different sets of ion chromatography equipment. The anions were determined on a Dionex DX-3000 system with external suppression. For standard runs, a $25 \mu \mathrm{l}$ sample loop was used.
The cations were analyzed using a Dionex DX-120 system with electrochemical micromembrane suppression and a $25 \mu \mathrm{l}$ sample loop. Standards were made from commercially available reference material (Merck, Certipur ${ }^{\circledR}$ ). The samples were diluted with Milli-Q ${ }^{\circledR} 1: 100$ before analysis. For all steps in the analytical procedure, Milli-Q water was used, the analyzed components in the blank were always below detection limit. The detection limits [ppb] were established as follows: $\mathrm{Li}, 0.1 ; \mathrm{Na}, 5 ; \mathrm{K}, 5 ; \mathrm{Ca}, 10 ; \mathrm{Mg}, 10 ; \mathrm{Cl}, 100 ; \mathrm{Br}, 5 ; \mathrm{F}$, 5; J, 0.1; and $\mathrm{SO}_{4}, 10$.

The oxygen isotopic composition $\left(\delta^{18} \mathrm{O}\right)$ of the water samples was measured by the $\mathrm{CO}_{2}-\mathrm{H}_{2} \mathrm{O}$ equilibrium technique [38] with a fully automated device adapted from Horita et al. [39] coupled to a Finnigan DELTAplus mass spectrometer. Horita et al. [39] designed an automated operating procedure to analyze hydrogen and oxygen isotope ratios of the same water samples without sample change. However, in this operating procedure, the equilibrium unit with the sample vials was shaken laterally at a few $\mathrm{Hz}$ for $4 \mathrm{~h}$ to enhance the isotopic exchange reaction. In the EQ-device used in this study, the water sample is stirred individually in each vial. This leads to a higher precision of the isotope measurements. The temperature of the water bath was $24^{\circ} \mathrm{C} \pm 0.1^{\circ} \mathrm{C}$ during water- $\mathrm{CO}_{2}$ equilibration. Measurement reproducibility of duplicates was better than $\pm 0.05 \%$ for $\delta^{18} \mathrm{O}$. Deuterium $\left(\delta^{2} \mathrm{H}\right)$ was measured with a Finnigan DELTAplus XP continuous flow stable isotope ratio mass spectrometer by chromium reduction using a ceramic reactor slightly modified from Morrison et al. [40]. The analytical precision of the $\delta^{2} \mathrm{H}$ measurements was better than $1.5 \%$. Normalization of the raw results versus the V-SMOWSLAP scale was achieved by using a four-point calibration of in-house water standards that have been calibrated against 
the international reference materials V-SMOW, GISP, and VSLAP. No further corrections were applied. Stable hydrogen and oxygen isotopes of water are expressed against V-SMOW.

Oils were separated from water and treated to remove asphaltenes: $50 \mathrm{mg}$ of oil was diluted in $n$-pentane and the insoluble fraction was separated by centrifuging. The pentane-soluble fractions were analyzed using a gas chromatograph (GC) equipped with a J\&W DB-1 PONA ( $50 \mathrm{~m}$ length, ID $0.2 \mathrm{~mm}, 0.5 \mu \mathrm{m}$ film thickness) fused silica capillary column. The sample was injected in split mode at $270^{\circ} \mathrm{C}$. The GC oven temperature was programmed as follows: $32^{\circ} \mathrm{C}$ hold for $5 \mathrm{~min}$ followed by heating $2.5^{\circ} \mathrm{C} / \mathrm{min}$ to $310^{\circ} \mathrm{C}$ and hold for $30 \mathrm{~min}$. Helium was used as carrier gas with a constant flow of $1.3 \mathrm{ml} / \mathrm{min}$. A flame ionization detector was operated at $320^{\circ} \mathrm{C}$ with gas flows of $350 \mathrm{ml} / \mathrm{min}$ and $35 \mathrm{ml} / \mathrm{min}$ for air and hydrogen, respectively.

\section{Results}

4.1. Water Samples. Total mineralization (total dissolved solids) of samples measured in the frame of this study varies between $1893.1 \mathrm{mg} / \mathrm{l}$ (sample U2; Cenomanian reservoir) and $18103.3 \mathrm{mg} / \mathrm{l}$ (sample N6; Eocene reservoir; Table 1). Notably, the average salinity of waters from Eocene reservoir $(10559.7 \mathrm{mg} / \mathrm{l})$ is higher than that of Cenomanian waters $(2958.5 \mathrm{mg} / \mathrm{l})$. This observation is also supported by data from industry (Eocene: 14164.5 mg/l; Cenomanian: $6222 \mathrm{mg} / \mathrm{l}$ ) and Andrews et al. ([7]; Eocene: $11738.1 \mathrm{mg} / \mathrm{l}$; Cenomanian: $2333.5 \mathrm{mg} / \mathrm{l}$; Tables 1 and 2). However, unusually low salinity water from Eocene reservoir is found in oil field D (samples D1-2; Tables 1 and 2) in the northeastern part of the study area. The most important dissolved ions are $\mathrm{Na}^{+}$and $\mathrm{Cl}^{-}$. In connate brines, these constituents are mainly derived from dissolved halite.

$\delta^{2} \mathrm{H}[\mathrm{V}-\mathrm{SMOW}]$ and $\delta^{18} \mathrm{O}[\mathrm{V}-\mathrm{SMOW}]$ values of water (measured in the frame of this study) from Eocene reservoir range from $-48.3 \%$ to $-12.9 \%$ and from $-7.1 \%$ to $0.6 \%$ for hydrogen and oxygen, respectively (Table 1). The isotopic composition of water from Cenomanian reservoir ranges from $-51.4 \%$ o to $-41.4 \%$ and from $-5.8 \%$ to $-4.8 \%$ o for hydrogen and oxygen, respectively.

4.2. Oil Samples. Oil samples are characterized by abundant $n$-alkanes up to $\mathrm{C}_{36}$. Because detailed information on biomarkers and stable isotopes based on the $\mathrm{C}_{15+}$ fractions has already been presented by Gratzer et al. [2] and Bechtel et al. [3], the present paper focuses on light hydrocarbons. The dominant light hydrocarbons are $n$-alkanes, although cycloalkanes and aromatics are also abundant. However, some oils are characterized by progressive depletion or almost entire removal of benzene, toluene, ethylbenzene, and xylenes (BTEX). To illustrate this phenomenon, the methylcyclohexane/toluene $(\mathrm{Mch} / \mathrm{Tol})$ and cyclohexane/benzene $(\mathrm{Ch} / \mathrm{B})$ ratios have been calculated (Table 1$)$, which vary widely from 1.7 to 98.2 and from 2.3 to 904 , respectively.

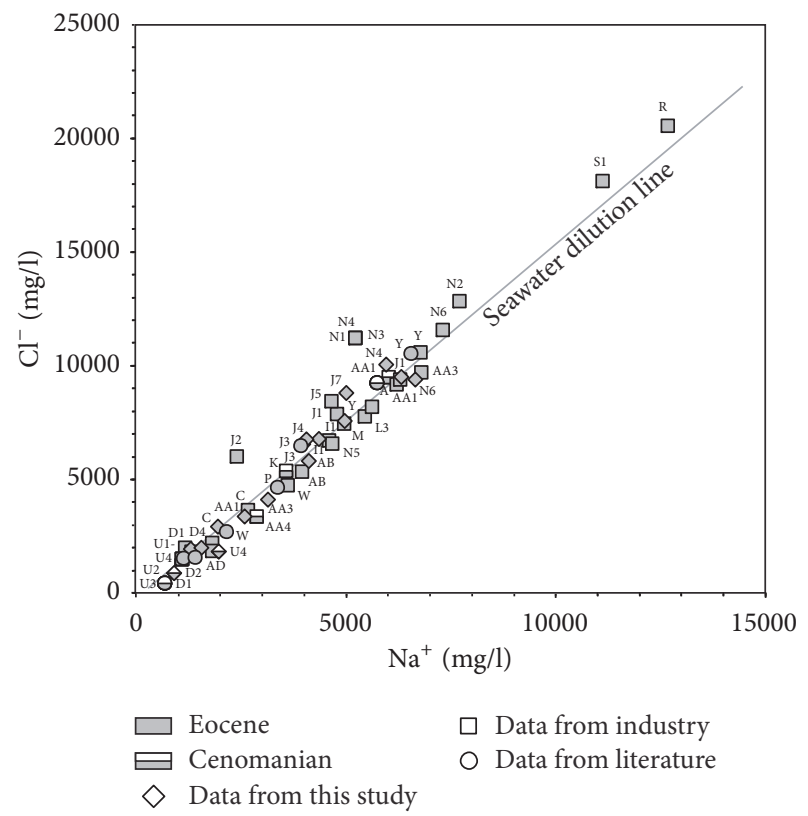

FIgURE 5: Cross-plot of $\mathrm{Na}^{+}$against $\mathrm{Cl}^{-}$dissolved in the water coproduced with oil. For comparison, data from this study are plotted together with industry and literature data. Deviation of the water from the seawater dilution line is probably caused by reservoir additives.

\section{Discussion}

5.1. Quality Control of Water Samples. To control the quality of samples with respect to possible influence of any reservoir additives used during oil production, the $\mathrm{Na}^{+}$and $\mathrm{Cl}^{-}$ concentrations are cross-plotted in Figure 5. No significant deviation from the sea water dilution line is observed, suggesting no influence from reservoir additives. Nevertheless, chlorine, which is considered as a conservative constituent, is used in further interpretation.

Lécuyer et al. [41] emphasized that the isotope fractionation factor between $\mathrm{CO}_{2}$ and $\mathrm{H}_{2} \mathrm{O}$ is salinity-dependent and that increasing salt contents $(\mathrm{KCl}$ or $\mathrm{NaCl})$ results in an increasing overestimation of oxygen isotope ratios. Because water samples investigated in the frame of this study are characterized by varying salinities, the potential effect on the study results has to be reviewed. The most saline water sample is sample N6 (18103.3 mg/l; Table 1), resulting in an overestimation of $\delta^{18} \mathrm{O}$ by less than $0.1 \%$, which is rather small but significant relative to analytical uncertainties. However, the quantification of the mixing between end-member waters from Malmian aquifer and Cenomanian/Eocene reservoirs performed by using ${ }^{2} \mathrm{H} /{ }^{1} \mathrm{H}$ and ${ }^{18} \mathrm{O} /{ }^{16} \mathrm{O}$ as natural traces will be negligently affected by lack of salinity-dependent corrections. In addition, it is unknown if the published isotopic compositions of samples were corrected. Therefore, the correction is not applied for the samples measured in the frame of this study.

5.2. Possible Processes Influencing the Light Hydrocarbon Fraction. The methylcyclohexane/toluene $(\mathrm{Mch} / \mathrm{Tol})$ and cyclohexane/benzene $(\mathrm{Ch} / \mathrm{B})$ ratios are cross-plotted in Figure 6 


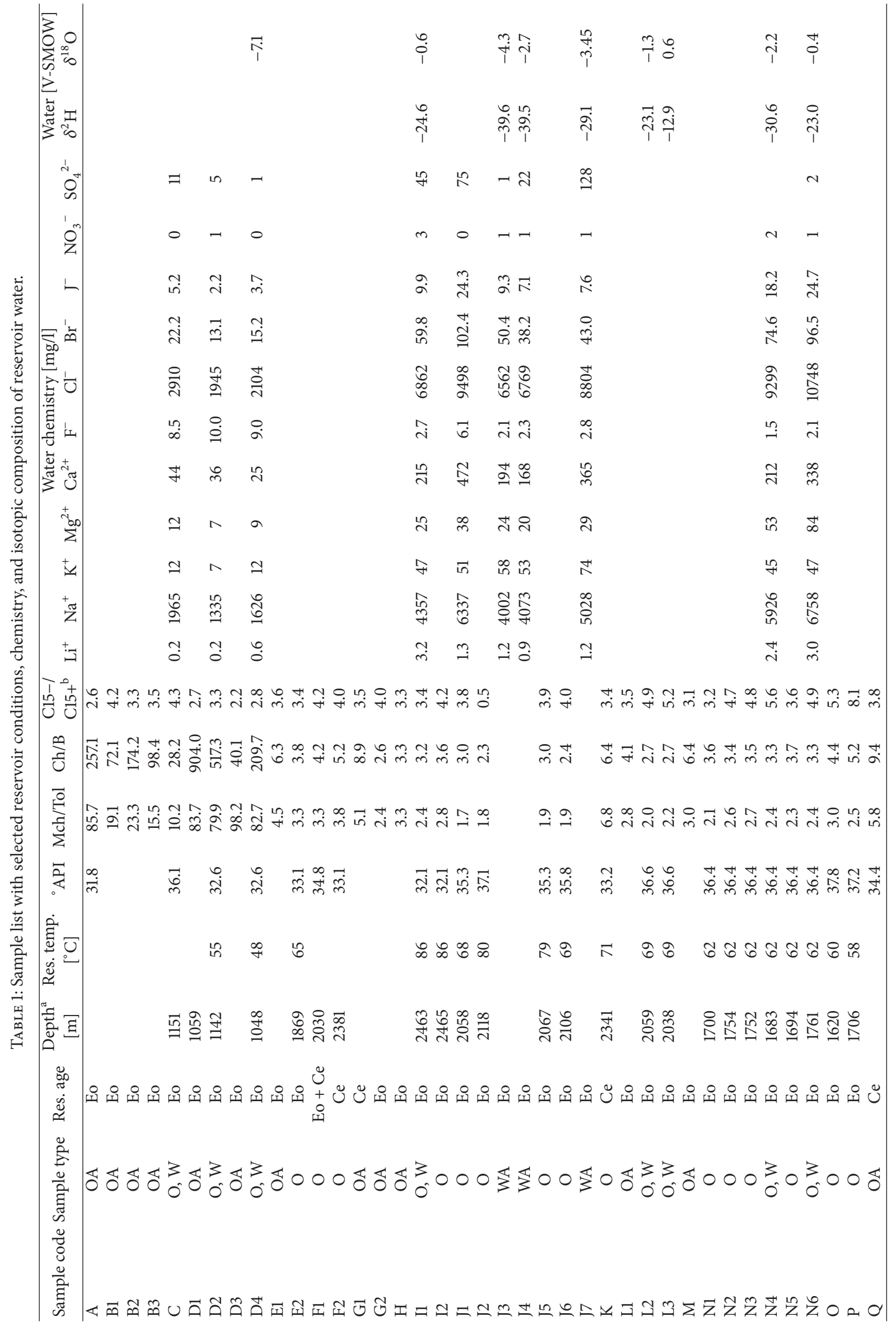




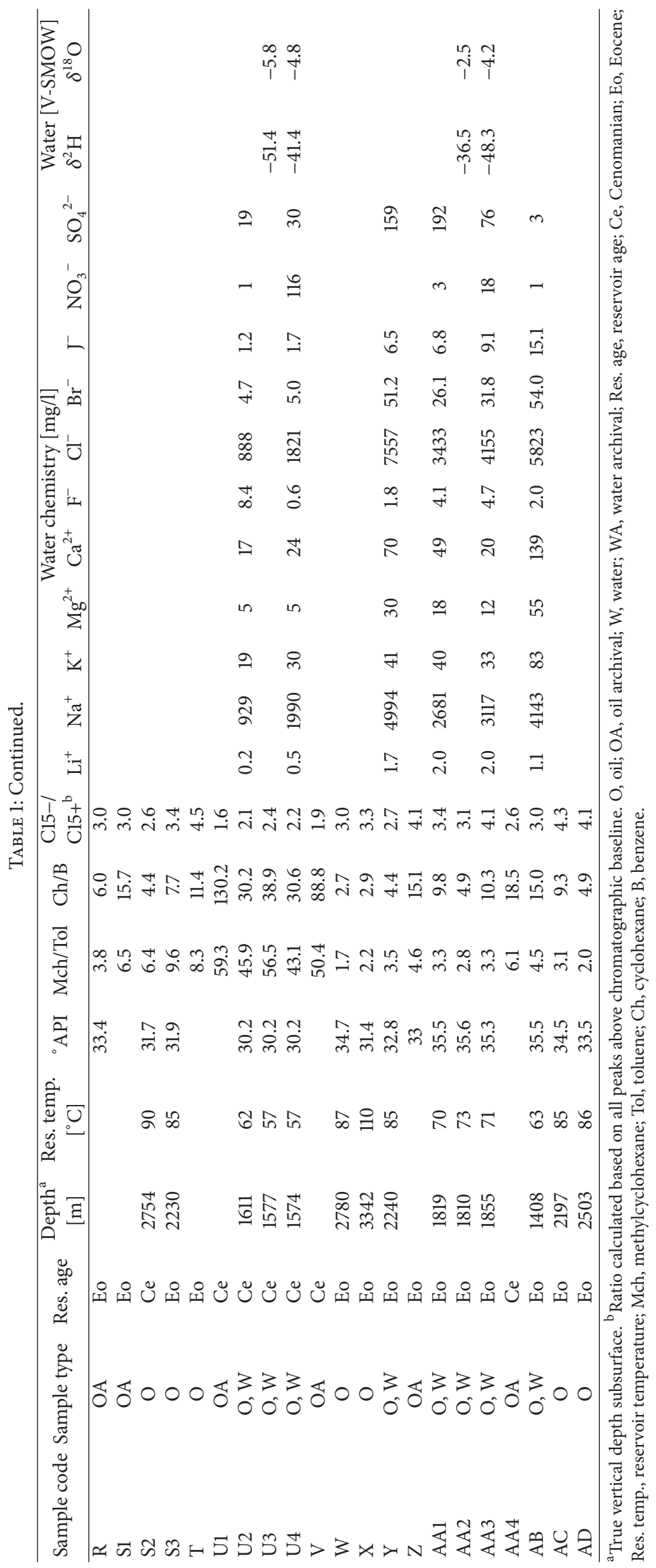




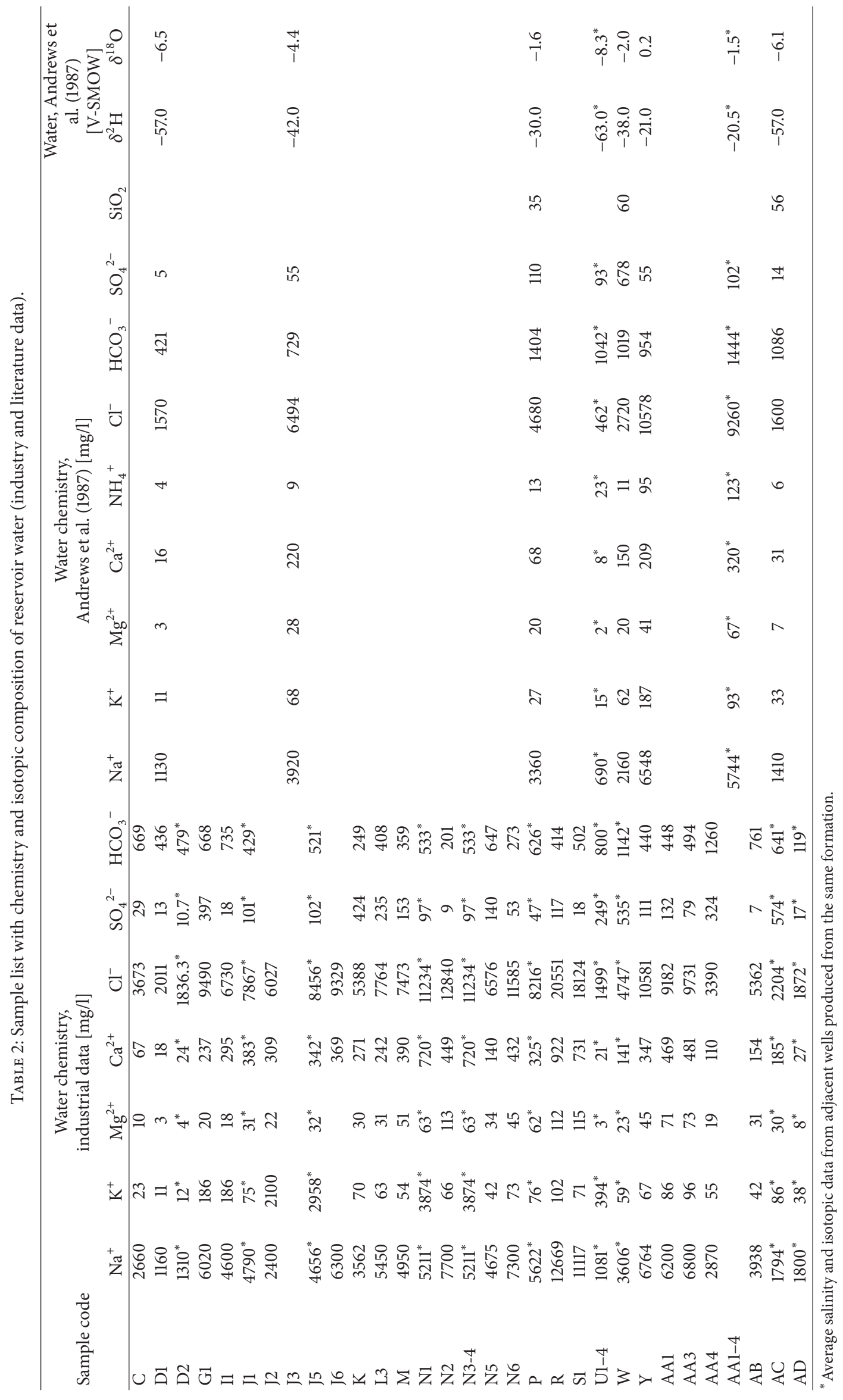




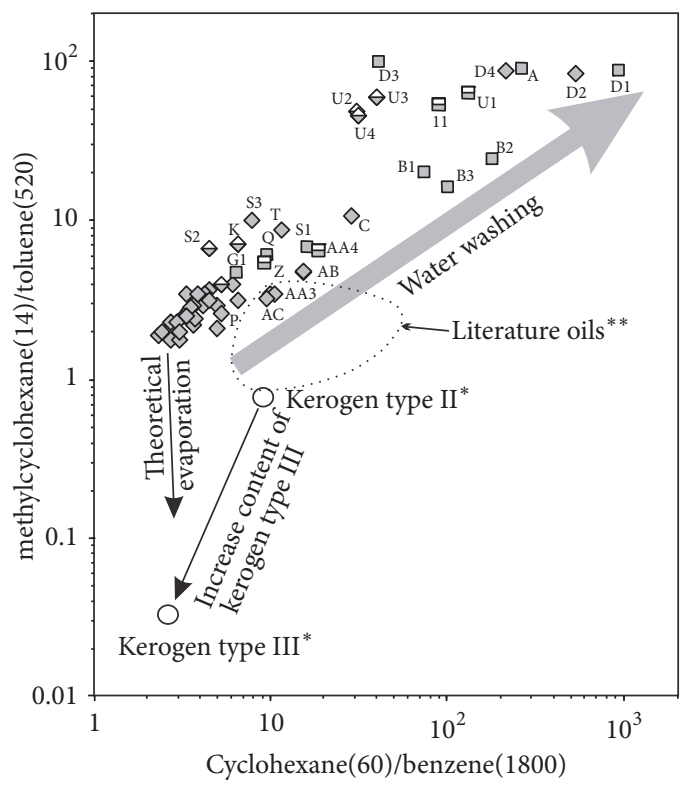

$\square$ Eocene
Eocene + Cenomanian
$\varnothing$ Cenomanian
$\diamond$ Oil sampled for this study
$\square$ Archival oil sample

FIGURE 6: Cross-plot of the methylcyclohexane/toluene (Mch/T) ratio versus the cyclohexane/benzene $(\mathrm{Ch} / \mathrm{B})$ ratio. Ratios are calculated from chromatographic peak areas. Solubilities (mg/l at $20^{\circ} \mathrm{C}$ ) of different compounds in water are given in brackets. Because aromatic compounds are more soluble in water, water washing results in an increase in $\mathrm{Mch} / \mathrm{T}$ and $\mathrm{Ch} / \mathrm{B}$ ratios. The theoretical evaporation trend, assuming simple mixtures of two compounds, is indicated (vapor pressure at $20^{\circ} \mathrm{C}$ for Mch: $48.3 \mathrm{hPa}$, Tol: $29.1 \mathrm{hPa}, \mathrm{Ch}: 104 \mathrm{hPa}, \mathrm{B}: 100 \mathrm{hPa}$ after [18]). ${ }^{*}$ Signature for kerogen type after Schaefer et al. [19]. Note that land plant-rich type III kerogen yields hydrocarbons with high contents of aromatic compounds resulting in very low $\mathrm{Mch} / \mathrm{T}$ and $\mathrm{Ch} / \mathrm{B}$ ratios. ${ }^{* *}$ Dotted line delineates typical $\mathrm{Mch} / \mathrm{T}$ and $\mathrm{Ch} / \mathrm{B}$ values from unaltered oils in the Rocky Mountain area [20], Gulf of Mexico (Pleistocene), California (Miocene), Louisiana (Lower Cretaceous [21]), North Slope (Alaska [22]), Mexican Gulf Coast Basin [23], North Central Sinai [24], and SW Barents Sea [25].

to show the significant variations in the relative contents of light hydrocarbon compounds between different oils. The observed differences may originate from natural primary and secondary processes as well as from poor storage of archival samples (e.g., changes due to evaporation losses). Therefore, it is critical to determine the consequences of each process that can generate compositional differences.

5.2.1. Influence of Source Rock Facies. Significant differences are observed in generation of hydrocarbons from marine and terrestrial organic matter. Type III kerogen yields predominantly aromatic hydrocarbons (e.g., benzene and toluene [19]), while type I/II kerogen produces more $n$-, iso-, and cycloalkanes (e.g., [42]). Moreover, Odden et al. [43] showed that increasing contents of terrigenous organic matter in source rocks results in higher concentration of aromatics, cyclohexane, and methylcyclohexane compared to cyclopentanes and acyclic hydrocarbons. Because the observed trend leads towards higher $\mathrm{Mch} / \mathrm{Tol}$ and $\mathrm{Ch} / \mathrm{B}$ ratios, increasing content of coaly facies in source rock can be ruled out (Figure 6).

5.2.2. Evaporative Fractionation. An alternative process that could influence the pattern of light hydrocarbons is called evaporative fractionation (Thompson, 1987) and describes the loss of light hydrocarbons from an oil phase (in reservoir or during migration) resulting from a later gas charge. During this process, the gas phase of a gas-saturated oil escapes from the oil, leaving behind residual oil strongly enriched in toluene and moderately enriched in cycloalkanes. In contrast, $n$-alkanes (e.g., heptane) will be preferentially dissolved in the escaping gas phase (Thompson, 1987). Therefore, evaporative fractionation would result in a trend opposite to the observed one (Figure 6).

\subsubsection{Evaporation Losses of Light Fraction during Sample} Handling. The current study is based on the quantification of relative volatile hydrocarbons. Therefore, it is critical to discuss the effect of possible losses caused by evaporation during sampling, storage, or laboratory handling. Evaporation of hydrocarbons depends on different factors like group type (linear, branched, cyclic, and aromatic), isomeric structure, molecular weight, and bulk composition of the sample [44]. However, laboratory controlled evaporation of crude oil showed that this process is primarily controlled by differences in boiling points [23]. Consequently, based on differences in vapor pressure of mixtures of two components ( $\mathrm{Mch} / \mathrm{Tol}$; $\mathrm{Ch} / \mathrm{B}$ ), it is possible to estimate general evaporation trends. Thus, incidental loss of light hydrocarbons will result in a strong decrease of the Mch/Tol ratio and a small increase in the $\mathrm{Ch} / \mathrm{B}$ ratio (see Figure 6). Hence, evaporation cannot explain the observed strong increase in $\mathrm{Mch} / \mathrm{Tol}$ and $\mathrm{Ch} / \mathrm{B}$ ratios, although a minor effect on samples, which have been stored for a long time (archive samples), cannot be ruled out completely.

5.3. Oil-Water Interaction. In the previous section, it could be shown that source rock facies, evaporative fractionation, and losses during sample storage and handling are not responsible for the observed BTEX depletion. In contrast, the trend in Figure 7 is interpreted to reflect the selective removal of relatively soluble aromatics during contact with water. The oil-water interaction can occur during the migration from the source rock to the reservoir and/or after oil accumulation in the reservoir. The longer the migration distance, the higher the potential interaction between oil and water. Interestingly, there is no correlation between migration distance and BTEX depletion. For example, samples A and P experienced similar migration distance ( $\sim 35 \mathrm{~km}$ according to [3]; see Figure 1(c) for sample location), but only sample A is strongly depleted in aromatic hydrocarbons $(\mathrm{MCH} / \mathrm{Tol}+\mathrm{Ch} / \mathrm{B}=342.8)$. In comparison, the sum of $\mathrm{MCH} / \mathrm{Tol}$ and $\mathrm{Ch} / \mathrm{B}$ is only 7.7 for sample $\mathrm{P}$. The same is true for the strongly altered U1-4 samples (average $\mathrm{MCH} / \mathrm{Tol}+\mathrm{Ch} / \mathrm{B}=108.7$ ) and the less affected $\mathrm{AB}$ sample $(\mathrm{MCH} / \mathrm{Tol}+\mathrm{Ch} / \mathrm{B}=19.5)$ which 


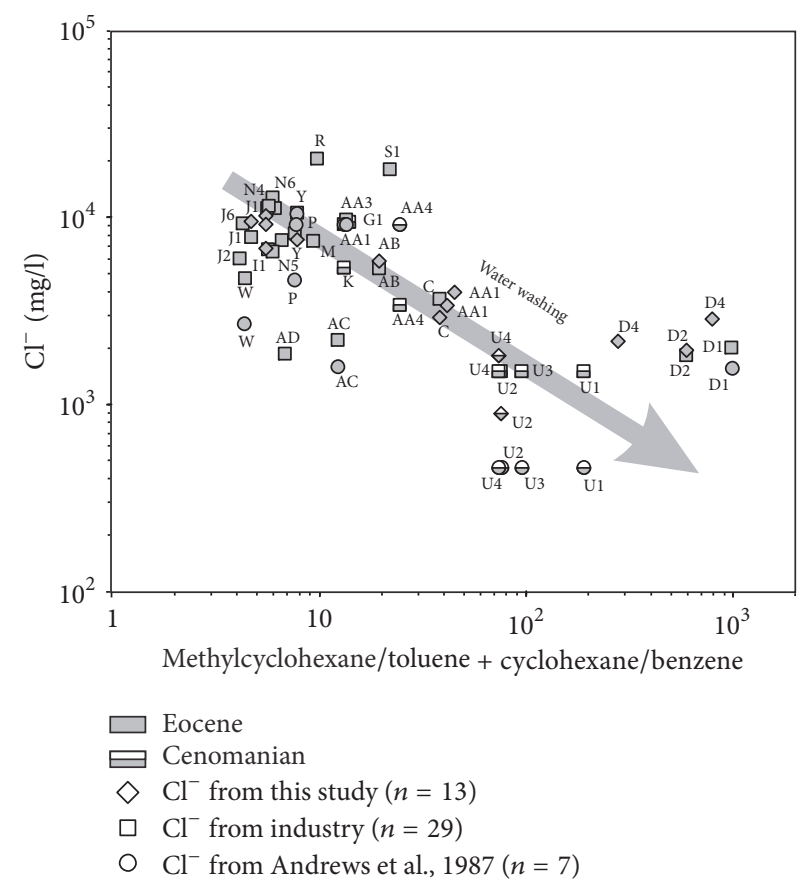

(a)

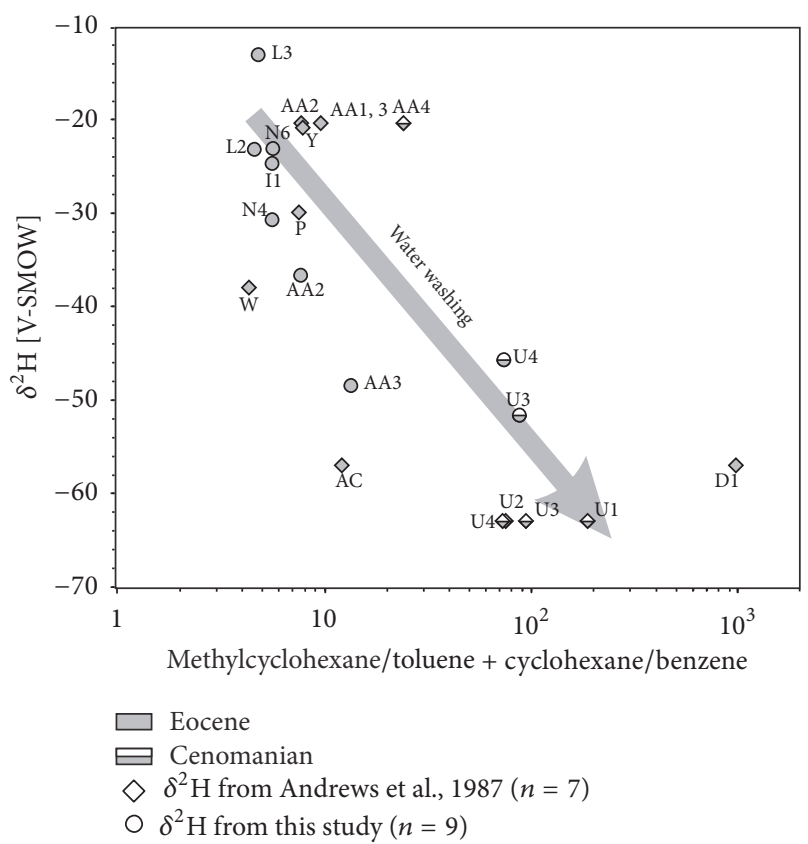

(b)

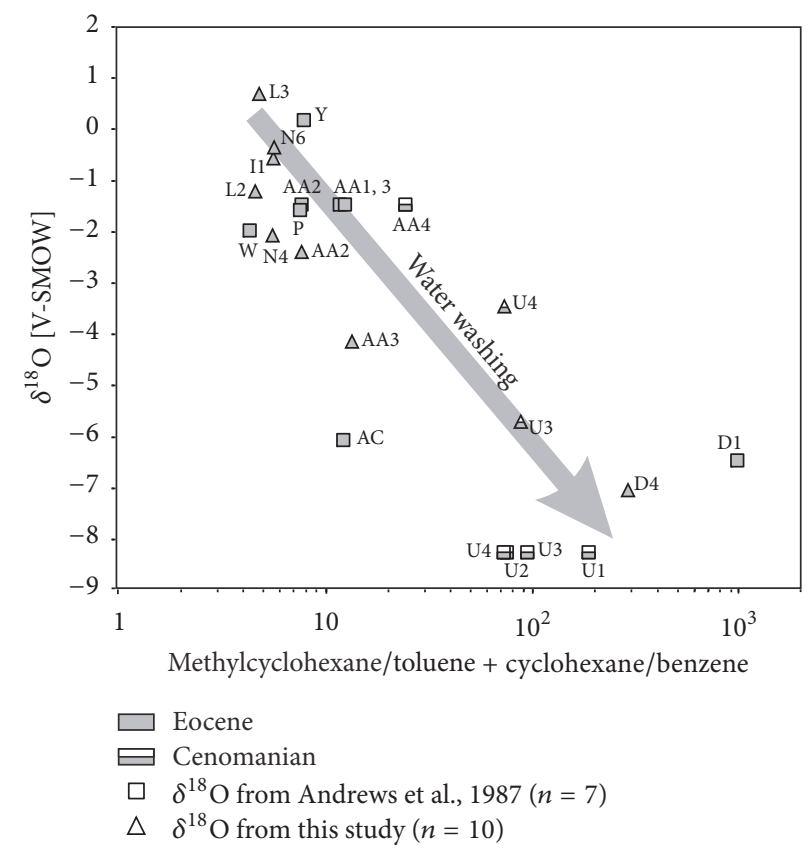

(c)

FIGURE 7: Cross-plots of the sum of two ratios between cycloalkanes and aromatic hydrocarbons versus (a) chlorine $\left(\mathrm{Cl}^{-}\right)$content in reservoir waters, (b) stable hydrogen isotope ratios of reservoir waters, and (c) stable oxygen isotope ratios of reservoir waters. For sample location, see Figure 1(c).

show similar migration distances. Therefore, the observed water washing phenomenon is most probably not controlled migration distance. Hence, water washing probably occurs in the reservoir.

Significant removal of BTEX from bulk oil composition requires a sufficient volume of BTEX-undersaturated water. Considering hydrostatic conditions, it is unlikely that the concentration gradient between oil and the volume of associated water would be high enough to explain the observed strong BTEX depletion. This suggests that water washing is related to the Malmian aquifer, which is the only main aquifer, which is under dynamic condition and, thus, may provide sufficient undersaturated water that drives diffusion. 

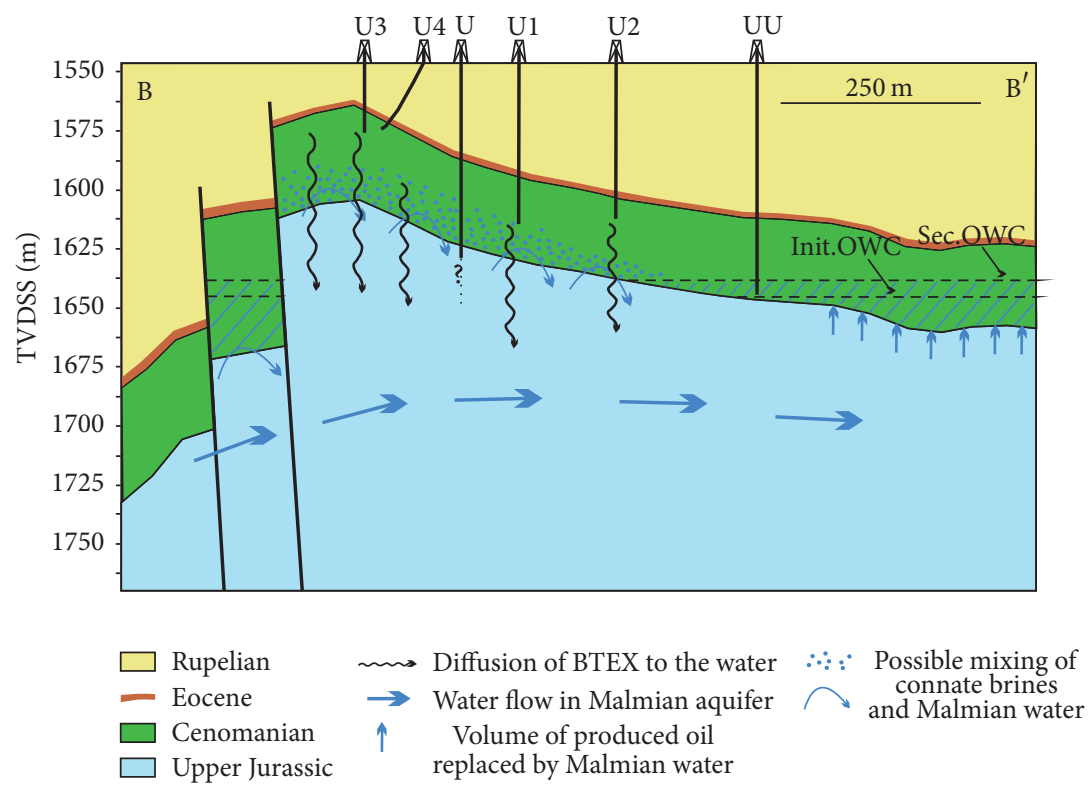

FIGURE 8: Simplified cross section of the oil field and location of U1-U4 samples. Well U is used for reinjection of thermal water produced from Malmian (Upper Jurassic) horizon by a well located $3 \mathrm{~km}$ west of the section. Well UU is used as reinjector for reservoir brines coproduced with oil. Init. OWC: initial oil-water-contact at the beginning of oil production. Sec. OWC: secondary oil-water-contact estimated after 40 years of production. TVDSS: true vertical depth subsea.

Because water from this aquifer is characterized by low salinity and light isotopic composition [7], water washing parameters are plotted against $\mathrm{Cl}^{-}$content, $\delta^{2} \mathrm{H}$ [V-SMOW] and $\delta^{18} \mathrm{O}$ [V-SMOW] values of water coproduced with oil in Figure 7. Indeed, increasing removal of BTEX components correlates with decreasing $\mathrm{Cl}^{-}$contents and isotope values (Figure 7). This shows that the original connate brines in water washed Cenomanian/Eocene reservoirs have been mixed with fresh water. The relation between water from the Malmian aquifer and water washed oil is especially obvious in the U field, where Cenomanian reservoir rocks directly overlie fresh water bearing Malmian carbonates (Figure 8 ). The high permeability of the Malmian carbonate, a prerequisite for significant water flow, is proven by losses of drilling mud (industry data) and allows the reinjection of thermal water in well $U$ (Figure 8, [26]).

5.4. Impact of Water Washing on Oil Properties. Water washing can significantly change oil properties. Lafargue and Barker [11] and Kuo [45] have shown that water washing can affect biomarker ratios, like the methyl phenanthrene index (MPI), a classical maturity parameter [46], and the dibenzothiophene/phenanthrene (DBT/Ph) ratio, a parameter that is often used for oil-source and oil-oil correlations [32]. Remarkably, samples from the water washed U field are characterized by the highest MPI value of all samples in the study area and a DBT/Ph ratio, which is lower than that in comparable oils [2]. Therefore, these parameters have to be used with caution for source rock and maturity evaluations for oil samples, suspected to be water washed.

Water washing reduces API gravity because it is particularly effective for $\mathrm{C}_{15-}$ hydrocarbons [11]. To test this hypothesis, the ratio of hydrocarbon fractions with less and more than 15 carbon atoms, respectively $\left(\mathrm{C}_{15_{-}} / \mathrm{C}_{15+}\right)$, is crossplotted versus the sum of two ratios between cycloalkanes and aromatic hydrocarbons in Figure 9(a). It shows that decreasing concentrations of aromatic hydrocarbons correlate fairly well with decreasing contents of light hydrocarbons. This indicates that, to some extent, API gravity of oils from AFB is controlled by water washing. To exclude any effect of losses of light hydrocarbons during sampling or handling, the $\mathrm{C}_{15-} / \mathrm{C}_{15+}$ ratio is plotted against industrial API gravity data, obtained during decades of production (Figure 9(b), Table 1).

Water washing is often accompanied by biodegradation. In the present case, water washed samples show no signs of biodegradation in the $n-\mathrm{C}_{7+}$ range. However, Gruner et al. [47] detected metabolites of BTEX in reservoir water from water washed fields. This suggests that water washing facilitates biodegradation by making BTEX bioavailable.

5.5. Implication on the Understanding of Hydrological System. The Malmian hydrological system in the AFB is of great economic relevance, because it supplies a high number of hydrogeothermal installations and thermal spas. Assurance of sustainable use of the water is of prime importance and resulted in the establishment of a numeric, thermal hydraulic model ([8]; Figure 3).

The present study shows that heavily water washed fields occur in Cenomanian reservoirs in fields $\mathrm{U}$ and $\mathrm{V}$ and in Eocene reservoirs in fields A to D. Strong support for mixing of meteoric water and connate brine in these fields, $U$ and $\mathrm{D}$, is provided by the isotopic composition of water. For a simple quantification of mixing, two end-member waters are defined: (i) water from the Malmian aquifer and (ii) sample L3 from an Eocene reservoir (Table 1 and Figure 10). Based on this assumption, it is concluded that up to $77 \%$ of connate 


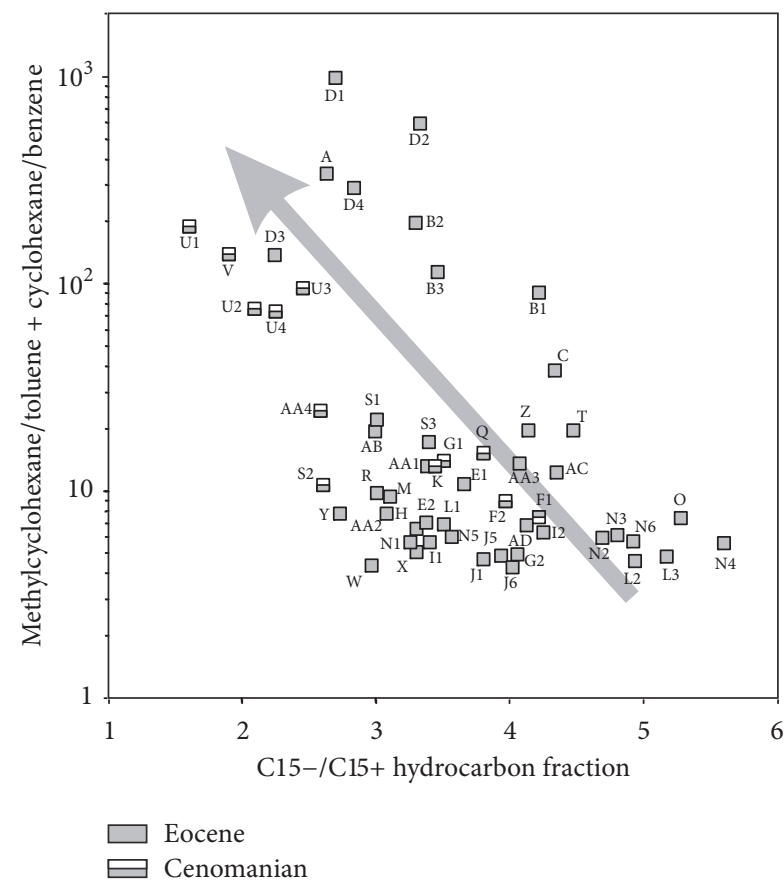

(a)

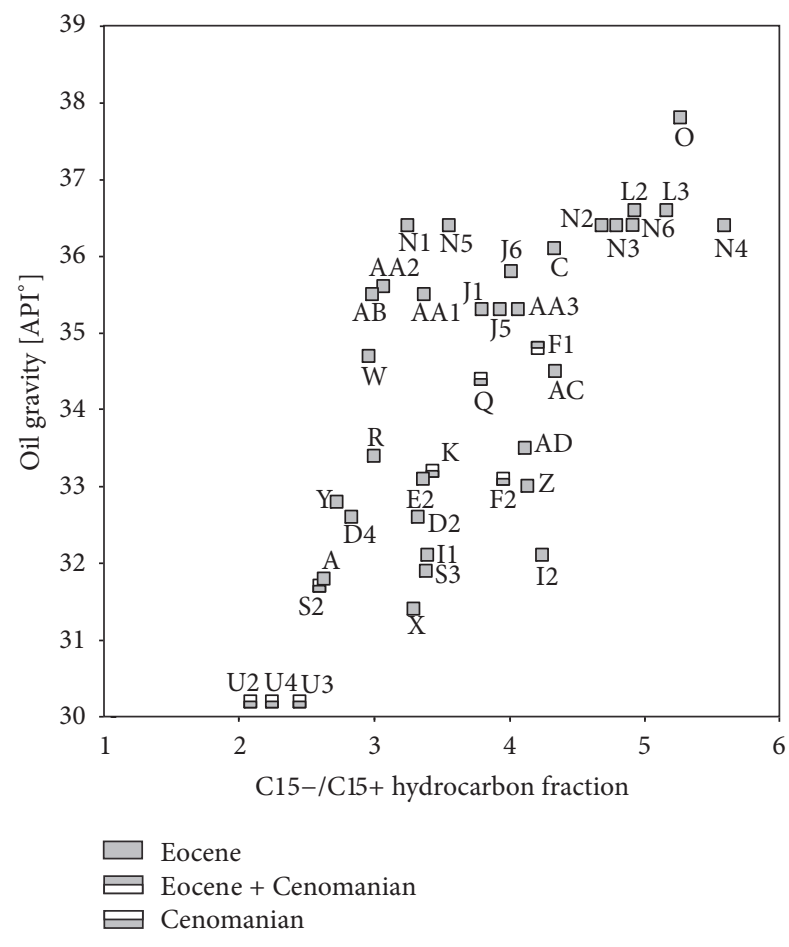

(b)

FiguRE 9: Cross-plots of the ratio of the sum of hydrocarbons with less than 15 carbon atoms over the sum of hydrocarbons with more than 15 carbon atoms $\left(\mathrm{C}_{15-} / \mathrm{C}_{15+}\right)$ versus (a) the sum of two ratios between cycloalkanes and aromatic hydrocarbons and (b) API oil gravity. Grey arrow indicates effect of water washing. For sample location, see Figure 1(c).

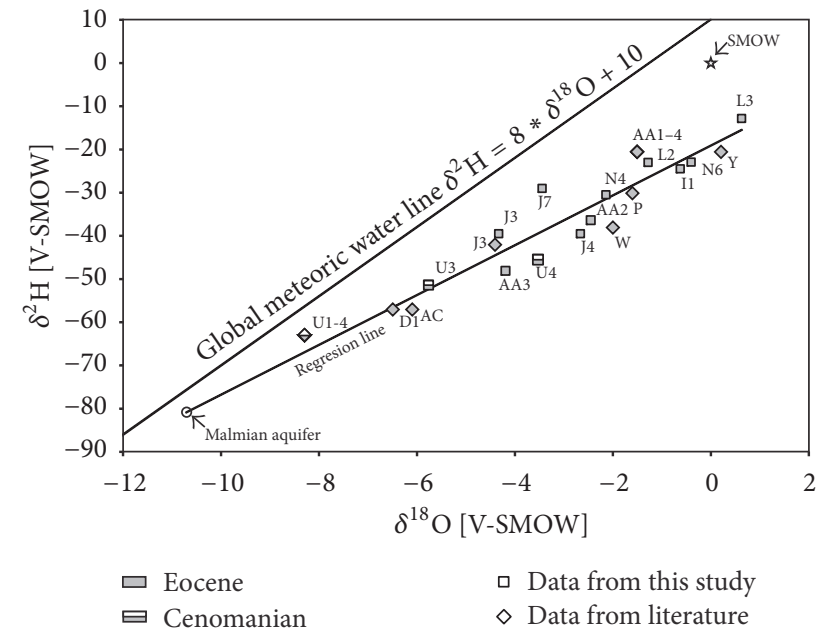

Figure 10: Cross-plots of $\delta^{2} \mathrm{H}$ [V-SMOW] versus $\delta^{18} \mathrm{O}$ [V-SMOW] values. Average isotopic values of Malmian aquifer are indicated after Andrews et al. [7], Goldbrunner [6], and Elster et al. [26]. For sample location, see Figure 1(c). According to Andrews et al. [7] and Goldbrunner [6], the regression line represents the mixing of connate brines and Malmian water.

Cenomanian/Eocene brine has been replaced by Malmian water in field $\mathrm{U}$. The percentage of meteoric water in field $\mathrm{D}$ is about $65 \%$.

As discussed above (Figure 8), water washing in the $U$ (and V) fields agrees with the current hydrogeological model.
However, field D is located east of the pinch-out of Malmian rocks and the Eocene reservoir directly overlies crystalline basement (Figure 3, [48, 49]). Moreover, field D is located outside the boundaries of the regional thermal water system, proposed by the Bayerisches Landesamt für Wasserwirtschaft [8] (Figure 3). Within this context, it is noteworthy that an extensive aquifer is indicated by a strong water drive keeping the reservoir pressure constant, despite of decades of oil production. Therefore, the boundaries of the established flow model need modifications. In contrast to oils from the northern part of study area, oils from the southern part typically show no evidence of water washing (e.g., E, I, J, and $\mathrm{T}$ fields; Figure 6). This is in agreement with stagnant conditions in the reservoir and the Malmian aquifer in this area (Figure 3).

\section{Conclusions}

Light hydrocarbon geochemistry of 57 oil samples from Cenomanian and Eocene reservoirs in the Austrian sector of the Alpine Foreland Basin has been investigated in the frame of this study. Strong depletion of BTEX compounds in some oils implies water washing. Additional observed features of water washing include a decrease in API gravity related to depletion in low molecular saturated components.

Water coproduced with water washed oil shows a progressive reduction in chlorine content (min.: $888 \mathrm{mg} / \mathrm{l}$, measured in the frame of this study) and depletion in ${ }^{2} \mathrm{H}$ and ${ }^{18} \mathrm{O}$ isotopes ( -51.4 and -5.8 , resp., measured in the frame of 
this study), indicating that connate brines have been partly replaced by meteoric water characteristic of the underlying Malmian carbonates, the main aquifer for geothermal water in the basin.

Most strongly affected oils are located in the shallow northern and northeastern part of the study area (fields A, $\mathrm{D}, \mathrm{U}$, and $\mathrm{V}$ ). The $\mathrm{U}$ and $\mathrm{V}$ fields produce from Cenomanian reservoirs directly overlying the Malmian aquifer. In these fields, a hydraulic connectivity between the reservoir and the aquifer could be proven. Fields A and D are located east of the extension of the Malmian aquifer and produce from Eocene reservoirs. The Eocene reservoir rocks of field D rest directly on crystalline basement. This suggests that Malmian water is discharged (north-eastwards) through crystalline basement rocks and that previous flow models of the regional geothermal aquifer have to be reevaluated.

In contrast to the shallow northern fields, fields in the deep southern part of the basin (e.g., E-J, L-P, R, W-Z, and AD) are apparently not affected by water washing. The water in these fields shows relatively high salinity.

The results emphasize the importance of combining data from the petroleum and geothermal industry, which are often handled separately: recognition of active water flow may help to predict gravity and viscosity anomalies, biodegradation risk, and the presence of hydrodynamic traps. Additionally, identification of water washing helps to improve flow models of the underlying Malmian aquifer.

\section{Conflicts of Interest}

The authors declare that there are no conflicts of interest regarding the publication of this paper.

\section{Acknowledgments}

The authors would like to acknowledge Rohöl-Aufsuchungs AG for access to samples, geological documentation, and publication permission. Collaboration with Christoph Janka, Rohöl-Aufsuchungs AG, led to the understanding expressed in this paper. The presented data were obtained within the frame of FFG Bridge Project 836527 between Montanuniversität Leoben and Rohöl-Aufsuchungs AG. The authors would like to thank Johannes Rauball for linguistic corrections.

\section{References}

[1] R. F. Sachsenhofer, B. Leitner, H.-G. Linzer et al., "Deposition, erosion and hydrocarbon source potential of the Oligocene Eggerding Formation (Molasse Basin, Austria)," Austrian Journal of Earth Sciences, vol. 103, no. 1, pp. 76-99, 2010.

[2] R. Gratzer, A. Bechtel, R. F. Sachsenhofer, H.-G. Linzer, D. Reischenbacher, and H.-M. Schulz, "Oil-oil and oil-source rock correlations in the Alpine Foreland Basin of Austria: Insights from biomarker and stable carbon isotope studies," Marine and Petroleum Geology, vol. 28, no. 6, pp. 1171-1186, 2011.

[3] A. Bechtel, R. Gratzer, H.-G. Linzer, and R. F. Sachsenhofer, "Influence of migration distance, maturity and facies on the stable isotopic composition of alkanes and on carbazole distributions in oils and source rocks of the alpine foreland basin of Austria," Organic Geochemistry, vol. 62, pp. 74-85, 2013.
[4] K. E. Peters, C. C. Walters, and J. M. Moldowan, The Biomarker Guide Volume I Biomarkers and Isotopes in Environment and Human History, 2005.

[5] J. Goldbrunner, "Austria - country update," in Proceedings of the World Geothermal Congress, Melbourne, Australia, April 2015.

[6] J. E. Goldbrunner, "Geothermal Exploitation in the Upper Austrian Molasse Basin," Beiträge zur Hydrogeologie, vol. 59, pp. 187-202, 2012.

[7] J. N. Andrews, M. J. Youngman, J. E. Goldbrunner, and W. G. Darling, "The geochemistry of formation waters in the molasse basin of upper Austria," Environmental Geology and Water Sciences, vol. 10, no. 1, pp. 43-57, 1987.

[8] Bayrisches Landesamt für Wasserwirtschaft, 1999. Das Thermalwasservorkommen im niederbayerisch-oberösterreichischen Molassebecken, Hydrogeologisches Modell und Thermalwasser Strömungsmodell im Auftrag des Freistaates Bayern und der Republik Österreich, Kurzbericht. München.

[9] J. E. Goldbrunner, "Hydrogeology of deep groundwaters in Austria," Österreichische Geologische Gesellschaft, vol. 92, no. 1999, pp. 281-294, 2000.

[10] D. Gross, R. Sachsenhofer, A. Rech et al., “The trattnach oil field in the north alpine foreland basin (Austria)," Austrian Journal of Earth Sciences, vol. 108, no. 2, pp. 151-171, 2015.

[11] E. Lafargue and C. Barker, "Effect of water washing on crude oil compositions," American Association of Petroleum Geologists Bulletin, vol. 73, no. 3, pp. 263-276, 1988.

[12] E. Lafargue and P. Le Thiez, "Effect of waterwashing on light ends compositional heterogeneity," Organic Geochemistry, vol. 24, no. 12, pp. 1141-1150, 1996.

[13] N. J. L. Bailey, H. R. Krouse, C. R. Evans, and M. A. Rogers, "Alteration of crude oil by waters and bacteria - evidence from geochemical and isotope studies," The American Association of Petroleum Geologists Bulletin, vol. 57, pp. 1276-1290, 1973.

[14] S. E. Palmer, "Effect of Water washing on C15+ hydrocarbon Fraction of Crude Oils from Northwest," American Association of Petroleum Geologists Bulletin, vol. 68, pp. 137-149, 1984.

[15] W. Nachtmann and L. Wagner, "Mesozoic and early tertiary evolution of the alpine foreland in upper Austria and Salzburg, Austria," Tectonophysics, vol. 137, no. 1-4, pp. 61-76, 1987.

[16] L. R. Wagner, "Stratigraphy and hydrocarbons in upper Austrian Molasse Foredeep (active margin)," in Oil and Gas in Alpidic Thrust belts and Basins of Central and Eastern Europe, Wessely. G. and W. Liebl, Eds., vol. 5, pp. 217-235, European Association of Geoscientists and Engineers Special Publication, 1996.

[17] P. Grunert, G. Auer, M. Harzhauser, and W. E. Piller, "Stratigraphic constraints for the upper Oligocene to lower Miocene Puchkirchen group (North Alpine Foreland Basin, Central Paratethys)," Newsletters on Stratigraphy, vol. 48, no. 1, pp. 111133, 2015.

[18] http://gestis-en.itrust.de/nxt/gateway.dll/gestis_en/000000.xml? $\mathrm{f}=$ templates $\$ \mathrm{fn}=$ default.htm $\$$ vid=gestiseng:sdbeng\%.0.

[19] R. G. Schaefer, H. von der Dick, and D. Leythaeuser, " $\mathrm{C}_{2}-\mathrm{C}_{8}$ hydrocarbons in sediments from deep sea drilling project leg 71, site 511, Falkland Plateau, South Atlantic," in Initial Reports of The Deep Sea Drilling Project 71, J. H. Blakeslee and M. Lee, Eds., 1983.

[20] J. G. Erdman and D. A. Morris, "Geochemical correlation of petroleum," The American Association of Petroleum Geologists Bulletin, vol. 58, pp. 2326-2337, 1974. 
[21] K. F. M. Thompson, "Light hydrocarbons in subsurface sediments," Geochimica et Cosmochimica Acta, vol. 43, no. 5, pp. 657-672, 1979.

[22] W. D. Masterson, L. I. P. Dzou,, A. G. Holba, A. L. Fincannon, and L. Ellis, "Evidence for biodegradation and evaporative fractionation in West Sak, Kuparuk and Prudhoe Bay field areas, North Slope, Alaska," Organic Geochemistry, vol. 32, no. 3, pp. 411-441, 2001.

[23] N. K. Cañipa-Morales, C. A. Galán-Vidal, M. A. Guzmán-Vega, and D. M. Jarvie, "Effect of evaporation on C7 light hydrocarbon parameters," Organic Geochemistry, vol. 34, no. 6, pp. 813-826, 2003.

[24] L. M. Sharaf and M. M. El Nady, "Application of light hydrocarbon $(\mathrm{C} 7+)$ and biomarker analyses in characterizing oil from wells in the North and North Central Sinai, Egypt," Petroleum Science and Technology, vol. 24, no. 6, pp. 607-627, 2006.

[25] W. A. Murillo, A. Vieth-Hillebrand, B. Horsfield, and H. Wilkes, "Petroleum source, maturity, alteration and mixing in the southwestern Barents sea: new insights from geochemical and isotope data," Marine and Petroleum Geology, vol. 70, pp. 119143, 2016.

[26] D. Elster, J. Goldbrunner, G. Wessely et al., Erläuterungen zur geologischen Themenkarte Thermalwässer in Österreich 1:500.000, Wien, 2016.

[27] J. E. Goldbrunner, "Zur Hydrogeologie des oberösterreichischen Molassebeckens. Steir," Beiträge zur Hydrogeologie, vol. 36, pp. 83-102, 1984.

[28] R. F. Sachsenhofer and H.-M. Schulz, "Architecture of Lower Oligocene source rocks in the Alpine Foreland Basin: a model for syn- and post-depositional source-rock features in the Paratethyan realm," Petroleum Geoscience, vol. 12, no. 4, pp. 363$377,2006$.

[29] J. Gusterhuber, R. Hinsch, H.-G. Linzer, and R. Sachsenhofer, "Hydrocarbon generation and migration from sub-thrust source rocks to foreland reservoirs: the Austrian Molasse Basin," Austrian Journal of Earth Sciences, vol. 106, pp. 115-136, 2013.

[30] J. Gusterhuber, I. Dunkl, R. Hinsch, H.-G. Linzer, and R. F. Sachsenhofer, "Neogene uplift and erosion in the Alpine Foreland Basin (Upper Austria and Salzburg)," Geologica Carpathica, vol. 63, no. 4, pp. 295-305, 2012.

[31] H.-G. Linzer, "Structural and stratigraphic traps in channel systems and intraslope basins of the deep-water molasse foreland basin of the Alps," in Proceedings of the AAPG Search and Discovery Article \#90007@2002 AAPG Annual Meeting, pp. 1-13, Houston, Tex, USA, 2002.

[32] W. B. Hughes, A. G. Holba, and L. I. P. Dzou, "The ratios of dibenzothiophene to phenanthrene and pristane to phytane as indicators of depositional environment and lithology of petroleum source rocks," Geochimica et Cosmochimica Acta, vol. 59, no. 17, pp. 3581-3598, 1995.

[33] H.-M. Schulz, W. van Berk, A. Bechtel, U. Struck, and E. Faber, "Bacterial methane in the Atzbach-Schwanenstadt gas field (Upper Austrian Molasse Basin), Part I: Geology," Marine and Petroleum Geology, vol. 26, no. 7, pp. 1163-1179, 2009.

[34] H.-M. Schulz and W. van Berk, "Bacterial methane in the Atzbach-Schwanenstadt gas field (upper Austrian Molasse Basin), Part II: retracing gas generation and filling history by mass balancing of organic carbon conversion applying hydrogeochemical modelling," Marine and Petroleum Geology, vol. 26, no. 7, pp. 1180-1189, 2009.

[35] J. A. Covault, S. M. Hubbard, S. A. Graham, R. Hinsch, and H.-G. Linzer, "Turbidite-reservoir architecture in complex foredeep-margin and wedge-top depocenters, Tertiary Molasse foreland basin system, Austria," Marine and Petroleum Geology, vol. 26, no. 3, pp. 379-396, 2009.

[36] S. M. Hubbard, M. J. de Ruig, and S. A. Graham, "Utilizing outcrop analogs to improve subsurface mapping of natural gasbearing strata in the Puchkirchen Formation, Molasse Basin, Upper Austria," Austrian Journal of Earth Sciences, vol. 98, pp. 52-66, 2005.

[37] S. M. Hubbard, M. J. de Ruig, and S. A. Graham, "Confined channel-levee complex development in an elongate depocenter: deep-water tertiary strata of the Austrian Molasse basin," Marine and Petroleum Geology, vol. 26, no. 1, pp. 85-112, 2009.

[38] S. Epstein and T. Mayeda, "Variation of $\mathrm{O}^{18}$ content of waters from natural sources," Geochimica et Cosmochimica Acta, vol. 4, no. 5, pp. 213-224, 1953.

[39] J. Horita, A. Ueda, K. Mizukami, and I. Takatori, "Automatic $\delta \mathrm{D}$ and $\delta 18 \mathrm{O}$ analyses of multi-water samples using $\mathrm{H} 2-$ and $\mathrm{CO} 2$-water equilibration methods with a common equilibration set-up," International Journal of Radiation Applications and Instrumentation, vol. 40, no. 9, pp. 801-805, 1989.

[40] J. Morrison, T. Brockwell, T. Merren, F. Fourel, and A. M. Phillips, "On-line high-precision stable hydrogen isotopic analyses on nanoliter water samples," Analytical Chemistry, vol. 73, no. 15, pp. 3570-3575, 2001.

[41] C. Lécuyer, V. Gardien, T. Rigaudier, F. Fourel, F. Martineau, and A. Cros, "Oxygen isotope fractionation and equilibration kinetics between $\mathrm{CO} 2$ and $\mathrm{H} 2 \mathrm{O}$ as a function of salinity of aqueous solutions," Chemical Geology, vol. 264, no. 1-4, pp. 122 126, 2009.

[42] D. Leythaeuser, R. G. Schaefer, and B. Weiner, "Generation of low molecular weight hydrocarbons from organic matter in source beds as a function of temperature and facies," Chemical Geology, vol. 25, no. 1-2, pp. 95-108, 1979.

[43] W. Odden, R. L. Patience, and G. W. Van Graas, "Application of light hydrocarbons (C4-C13) to oil/source rock correlations: a study of the light hydrocarbon compositions of source rocks and test fluids from offshore Mid-Norway," Organic Geochemistry, vol. 28, no. 12, pp. 823-847, 1998.

[44] K. F. M. Thompson, "Gas-condensate migration and oil fractionation in deltaic systems," Marine and Petroleum Geology, vol. 5, no. 3, pp. 237-246, 1988.

[45] L.-C. Kuo, "An experimental study of crude oil alteration in reservoir rocks by water washing," Organic Geochemistry, vol. 21, no. 5, pp. 465-479, 1994.

[46] M. Radke and D. H. Welte, "The methylphenanthrene index (MPI): a maturity parameter based on aromatic hydrocarbons," in Advances in Organic Geochemistry, M. Bjoroy, Ed., pp. 504512, Wiley, Chichester, England, 1983.

[47] A. Gruner, R. Jarling, A. Vieth-Hillebrand et al., "Tracing microbial hydrocarbon transformation processes in a high temperature petroleum reservoir using signature metabolites," Organic Geochemistry, vol. 108, pp. 82-93, 2017.

[48] G. Wessely, O. S. Schreiber, and R. Fuchs, "Lithofazies und mikrostratigraphie der Mittel- und Oberkreide des Molasseuntergrundes im östlichen Oberösterreich," Jahrbuch der Geologischen Bundesanstalt Band, vol. 124, pp. 175-281, 1981.

[49] A. Kröll, L. Wagner, and G. Wessely, 2006. Molassezone Salzburg - Oberösterreich 1:200.000: Geologische Karte der Molassebasis, Geol. Survesy Austria, Vienna. 

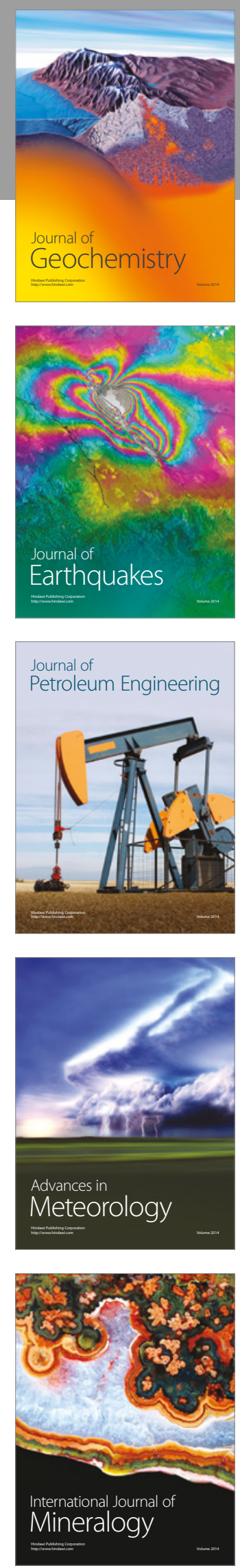
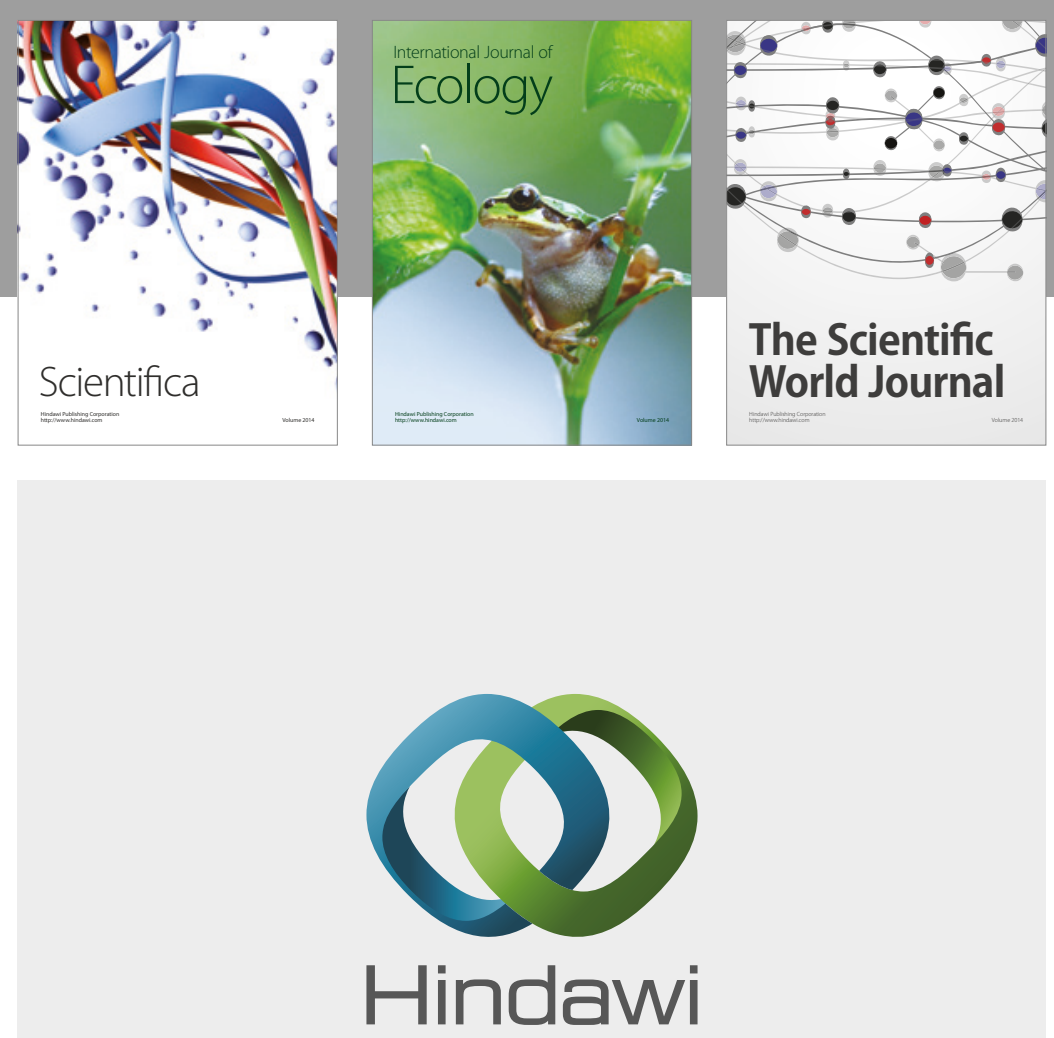

Submit your manuscripts at

https://www.hindawi.com
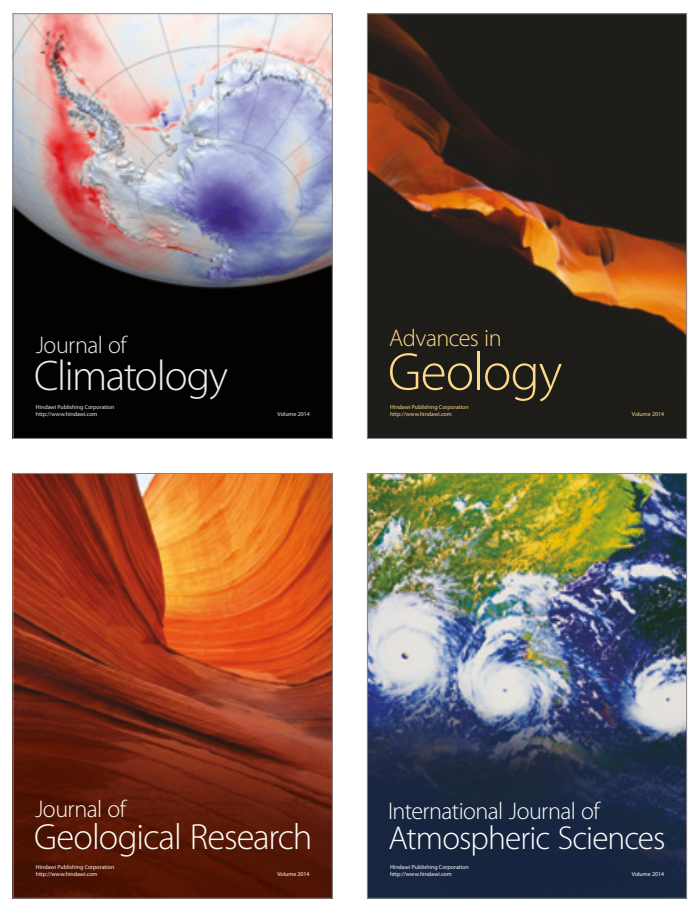

The Scientific

World Journal
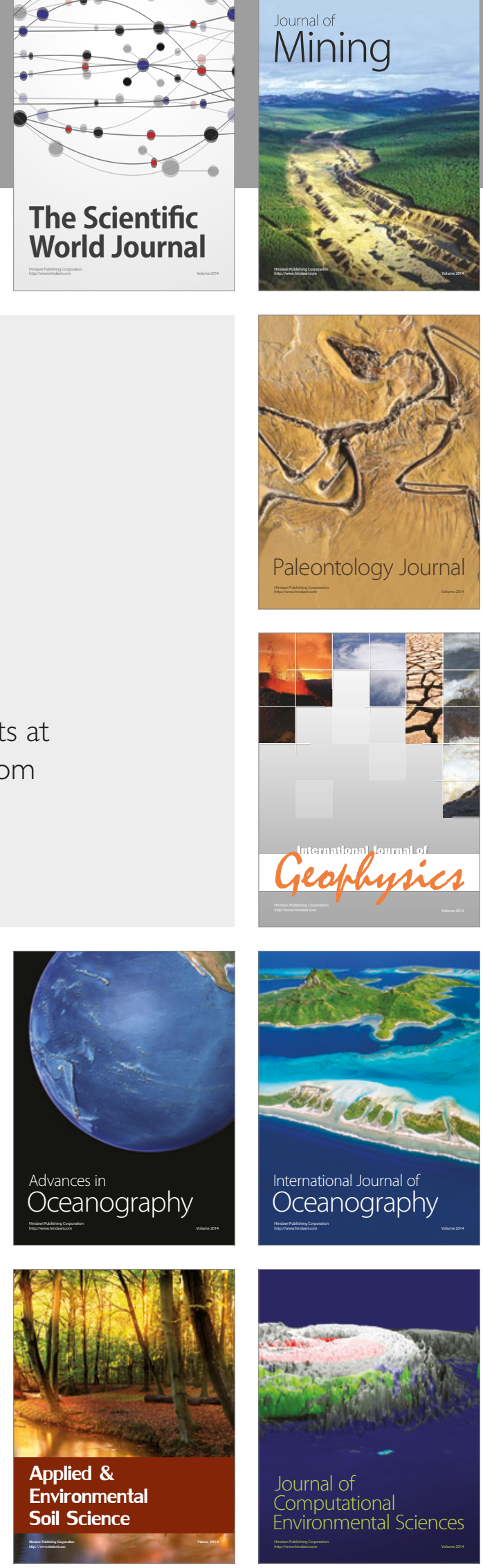